\title{
Effect of foresting barren ground with Macrocystis pyrifera (Linnaeus) C. Agardh on the occurrence of coastal fishes off northern Chile
}

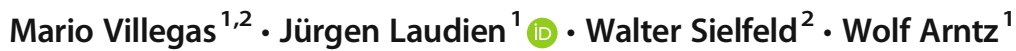 \\ Received: 13 June 2018 / Revised and accepted: 3 October 2018 / Published online: 29 November 2018 \\ (C) The Author(s) 2018
}

\begin{abstract}
Macrocystis pyrifera kelp beds play a significant ecological role along the coast of Chile. Besides their importance as food, protection structures, substrata, microhabitats and nurseries, regularly occurring natural disturbances (e.g. extremes of the climate variability El Niño-Southern Oscillation) and increased kelp exploitation affect these habitats. The present study aimed to test the dependence of reef fishes on Macrocystis pyrifera and to evaluate the effect of an enhanced habitat structure (experimental M. pyrifera bed) on the abundance, composition and spatial distribution on rock, on macroalgae, in the water column and on sand of the reef fish community. Boulders colonised by $M$. pyrifera were transported into three replicated experimental areas $\left(9 \mathrm{~m}^{2}\right.$ each) located in a barren ground area. Three barren ground areas $\left(9 \mathrm{~m}^{2}\right.$ each) without manipulation were selected as controls. The fish abundance, composition and spatial distribution on rock, on macroalgae, in the water column and on sand were recorded weekly by scuba diving over a period of 3 months, between 15 February 2007 and 13 June 2007 (4 months). Results indicate significantly higher abundances (mean $=225 \%$ ) of fishes in the forested areas compared to the barren ground controls (mean $=3.71$ fishes $/ 9 \mathrm{~m}^{2}$ and 1.14 fishes $/ 9 \mathrm{~m}^{2}$, respectively). Scartichthys gigas/viridis, Chromis crusma, Cheilodactylus variegatus and Isacia conceptionis numerically dominated the fish assemblages of the experimental kelp patches. Each fish species revealed different distributions in the forested areas: Scartichthys gigas/viridis was more abundant on rocks and C. variegatus in the macroalgae, whereas C. crusma and I. conceptionis preferred the water column above the experimental kelp bed. During the experimental time, the kelp lost some blades and some plants became detached. The overall number of fishes correlated with the declining kelp abundance $(r=0.964, p<0.05)$. The fish species showed different responses to these changes in the experimental areas: C. variegatus and I. conceptionis declined in abundance, whereas the abundance of Scartichthys gigas/ viridis remained constant.
\end{abstract}

Keywords Rockfishes · Fish behaviour · Foresting · Macrocystis pyrifera $\cdot$ Coastal Humboldt Current ecosystem

\section{Introduction}

The giant kelp Macrocystis pyrifera (Linnaeus) C. Agardh 1820, (synonym Macrocystis integrifolia Bory) is a characterising macroalga of shallow hard-bottom habitats off northern Chile (Dayton 1985; Vásquez 1992; Steneck et al. 2002; Villegas et al. 2008; Stotz et al. 2016). It forms vast kelp beds in the

Mario Villegas: deceased in March 2008

Jürgen Laudien

juergen.laudien@awi.de

Walter Sielfeld

walter.sielfeld.kowald@gmail.com

1 Alfred Wegener Institute Helmholtz Centre for Polar and Marine Research, Am Alten Hafen 26, 27568 Bremerhaven, Germany

2 Universidad Arturo Prat, Av. Arturo Prat 2120, Iquique, Chile
South Pacific from Paracas (Peru) to the Cape Horn Islands (Chile) and in the Northern Pacific along the west coast of the Baja California Peninsula (Mexico) up to Santa Cruz in Central California (USA) (Macaya and Zuccarello 2010). M. pyrifera is an important marine resource due to its high productivity, provision of habitat for settlement and development as well as food and shelter for a diverse array of organisms, including a number of commercially, artesanal and recreationally important fish and invertebrate species (e.g. Nuñez and Vásquez 1987; Carr 1991; Vásquez 1992; Angel and Ojeda 2001; Stachowicz 2001; Vásquez et al. 2001; Vega et al. 2005; Pérez-Matus et al. 2007, 2012, 2017; Villegas et al. 2008; Godoy et al. 2010; Gelcich et al. 2010; Stotz et al. 2016; Teagle et al. 2017; Miller et al. 2018). Several studies have described species composition, distribution (Vargas and Sielfeld 1997; Berrios and Vargas 2000) and trophic relations (e.g. Vásquez 1993; Berrios and Vargas 2004; Medina et al. 2004; Pérez-Matus et al. 2012) of these fish assemblages, suggesting that the 
composition may depend on prey (Medina et al. 2004). However, most of the forest fishes are plastic in their feeding preference along the coastline (Pérez-Matus et al. 2012) and a recent study from a northern Chilean kelp bed indicates that the invertebrate community structure does not strongly differ between alternative habitats (Villegas et al. submitted).

In coastal upwelling regions of the Northeast and Southeast Pacific, the regularly occurring extremes of the climate variability El Niño-Southern Oscillation (ENSO) result in alternative habitat states, i.e. dense kelp beds, kelp patches and deforested barren grounds (Tegner and Dayton 1987; Dayton and Tegner 1989; Foster and Schiel 1992; Vásquez 1992; Vega et al. 2005; Vásquez et al. 2006; Arntz et al. 2006; Graham et al. 2007; Villegas et al. 2008) due to variable physical factors (e.g. temperature and nutrient supply) (Buschmann et al. 2004; Pérez-Matus et al. 2007) and biological top-down effects, where shifts of grazers and carnivores control the kelp habitat structure (e.g. during the extreme cold phase of ENSO in 1999) (Vásquez and Vega 2004; Vega et al. 2005). In addition, storms detached entire plants from the substratum in California, which became entangled with attached plants either ripping them free or causing extensive stipe loss (Tegner and Dayton 1987; Dayton and Tegner 1989). A survey at Catalina Island in December 1984 also showed the complete loss of M. pyrifera at all depths (Foster and Schiel 1992).

Furthermore, there are increasing anthropogenic threats on northern Chilean M. pyrifera habitats. While until the year 2000 the Chilean kelp fishery was mainly sustained by the collection of naturally stranded seaweed on the shore, nowadays, driven mainly by international demands for raw material, M. pyrifera is intensively harvested (SERNAPESCA 1998-2009; Vásquez et al. 2012; Vega et al. 2014; Westermeier et al. 2014a, 2016). This kelp species is also needed as a feed input for the emerging abalone aquaculture industry (Buschmann et al. 2014). The fragmentation of kelp forests results in habitat loss. While Krumhansl et al. (2017) found only minimal impacts of small-scale harvest on kelp recovery rates, survival, biomass dynamics and abundances of kelp-associated fish species at the central coast of British Columbia, they detected a negative impact of warmer seawater temperatures on kelp recovery rates following harvest. This indicates that the viability of harvest, even at small scales, may be threatened by future increases in global sea surface temperatures (Krumhansl et al. 2017). These increases will affect kelp-associated fish assemblages and possibly cause shifts in the biogeographic distribution of species, resulting in novel interactions that have the potential to transform entire ecological communities (Vergés et al. 2016). The effects of kelp harvest on the ecology of the northern Chilean sublittoral system have not yet been analysed (Pérez-Matus et al. 2017). Any kelp bed reduction due to environmental changes and/or exploitation means (i) loss of refuge against predators which is particularly important for early life history stages (Carr 1994; Levin and Hay 1996; Carr and Reed 2015), (ii) loss of protection against wave impact reported by Vásquez and Santelices (1984) for Lessonia nigrescens, (iii) destruction of habitat for several invertebrate and fish taxa (Cancino and Santelices 1981; Pérez-Matus et al. 2007), (iv) a modification of vegetational strata (Santelices and Ojeda 1984 ) and (v) the elimination of a food resource for fishes (Medina et al. 2004; Ruz et al. 2018).

The need to assess recolonisation capacities and the design of restoration strategies led to transplanting Laminariales to restore areas where kelp had disappeared (McPeak 1977; Rice et al. 1989; Hernández-Carmona et al. 2000; Westermeier et al. 2016). Although time and labor intensive, foresting areas with juvenile and adult giant kelp or holdfast fragments rapidly provide fertile plants, which serve as a proximate source of propagules (McPeak 1977; Rice et al. 1989; HernándezCarmona et al. 2000; Westermeier et al. 2016). Even though M. pyrifera may naturally colonise former locations entirely, restoration can speed up this process (Hernández-Carmona et al. 2000; Correa et al. 2006; Westermeier et al. 2016). The response of economically important rockfish species to forested areas has, however, not been reported yet.

Previous studies on temperate seaweed beds and their associated invertebrate fauna in other geographic regions indicate that these habitats are important for reef fishes as they provide structural complexity, refuge from predators and serve as a food source (e.g. Ebeling and Hixon 1991; Levin and Hay 1996; Parsons et al. 2016; O'Brien et al. 2018). Implications of either the shifting or the elimination of temperate foundation kelp species for higher trophic levels were described by e.g. Terazono et al. (2012), Cheminée et al. (2017) and O’Brien et al. (2018).

The aim of the present study was to test the effect of kelp on the abundance, composition and spatial distribution of the rockfish community. Foresting experimental $M$. pyrifera beds and subsequent observation of the benthos and the rockfish community were performed to support conservation, restoration and management issues in the near future.

\section{Materials and methods}

\section{Study site}

The study was carried out at Chipana Bay $\left(21^{\circ} 20^{\prime} \mathrm{S}, 71^{\circ} 05^{\prime} \mathrm{W}\right)$ located $135 \mathrm{~km}$ south of Iquique City, northern Chile (Fig. 1). The North-South-oriented, 4-km-long bay has a north-westerly exposition. The Loa River discharges into the Coastal Pacific $10 \mathrm{~km}$ south of Chipana Bay. This influences the bay especially during El Niño (EN) - the warm phase of the ENSO - when run-off is significantly increased due to rainfall. Despite being a permanent coastal upwelling site with a constant oxygen 


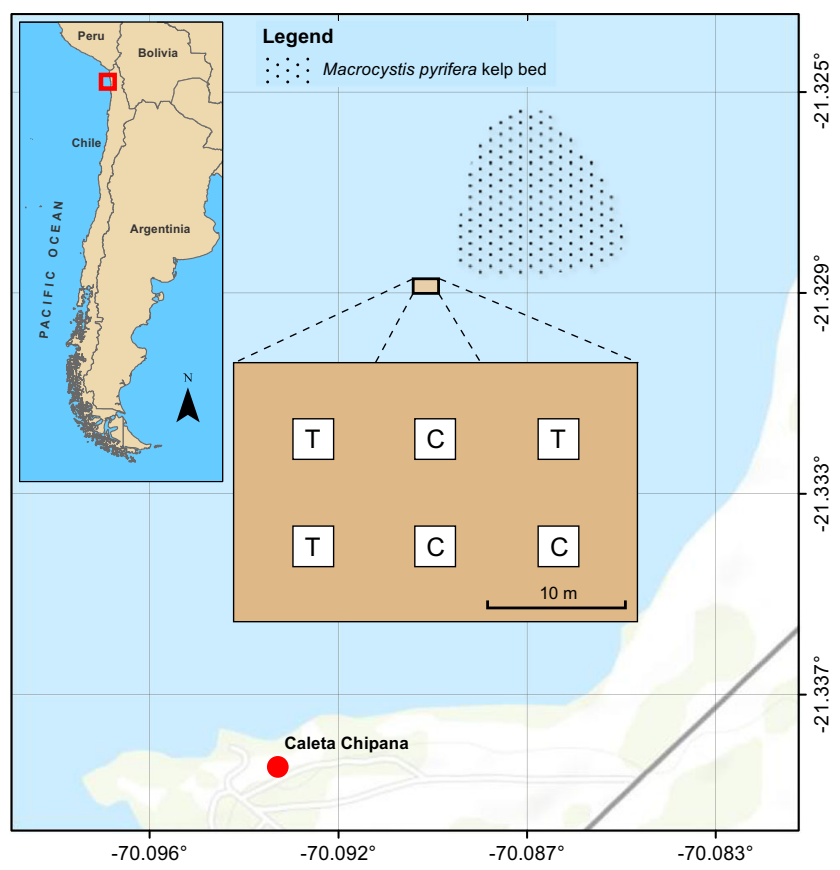

Fig. 1 Map showing the study site on a barren ground south-west of a Macrocystis pyrifera kelp bed off Chipana, northern Chile. Squared experimental ( $\mathrm{T}=$ treatment: forested $)$ and control plots $(\mathrm{C}=$ control: barren ground) had a side length of $3 \mathrm{~m}$ and an intercept of $6 \mathrm{~m}$

minimum zone and high planktonic production (Fuenzalida 1992; Santander et al. 2017), upwelling varies on a daily and weekly scale, modulating the composition of the phytoplankton community (Herrera and Escribano 2006; Aguilera et al. 2009). Chipana Bay has been described as a spawning site for small pelagic fish (Herrera and Escribano 2006; Palma et al. 2006). The shallow waters of the bay are characterised by extensive kelp beds and a rich and diverse fish fauna due to its protection as a 'prioritary site for conservation of biodiversity' (Chilean Ministry of Environment) (Rovira 2008; CONAMA 2008; Villegas et al., submitted). The sandy bay with shallow rocky areas provides substrate for a $M$. pyrifera kelp bed surrounded by barren ground. For details on habitat characteristics and the associated invertebrate community, see Villegas et al. (2008).

\section{Foresting barren ground with Macrocystis pyrifera}

In order to analyse the responses of the fishes to structural modification of their habitat (i.e. addition of kelp), an in situ experiment was carried out on a barren ground near the natural M. pyrifera kelp bed (Fig. 1). From the latter, boulders (diameter 30-60 cm) naturally colonised by $M$. pyrifera that extended to the water surface were collected by scientific scuba divers. The plants were transported in a tub, fixed $5 \mathrm{~m}$ underneath a fishing boat, to three replicated experimental plots ( $3 \mathrm{~m} \times 3 \mathrm{~m}$ each). The final kelp abundance of 28 plants/ $9 \mathrm{~m}^{2}$ resembled that of the kelp bed. Experimental plots were located at the same water depth in a nearby (distance $20 \mathrm{~m}$ ) area with similar boulders not colonised by $M$. pyrifera, but only by scattered algae, rising less than $40 \mathrm{~cm}$ above the substratum and covering, on average, less than a quarter of the plot area (i.e. Asparagopsis armata, Gelidium chilense, Glossophora kunthii, Halopteris hordacea, Rhodymenia cf. corallina, Ulva rigida and an unidentified Chlorophyta). Three unmanipulated square plots without kelp, but with the same macroalgae recorded in the treated plots, were marked in the area as control plots (Fig. 1). Due to a storm event, some M. pyrifera of the treatment were detached in the middle of the experiment and replaced between the second and third sampling. Thereafter, no restocking took place.

Fish abundance, composition and spatial distribution as well as abundance and composition of the benthos were recorded weekly by scientific scuba divers between 15 February 2007 and 11 April 2007, always choosing days with calm sea conditions. Within sampling units, one scuba diver counted all sporophytes present, while a second diver (always the same) recorded all fish species following modified procedures developed by Sale and Douglas (1981). The diver approached the marked plot and, at a distance of $4 \mathrm{~m}$, slowly unidirectionally circled the sampling unit while marking the spatial distribution of fishes on a check list for $5 \mathrm{~min}$. The diver then moved closer to the unit to record demersal species and searched the algae themselves. Because of difficult field identification of the giant blenny (Scartichthys gigas (Steindachner, 1876)) and the green blenny (Scartichthys viridis (Valenciennes, 1836)) due to their colour phases, sexual dimorphism and similar looking young stages, they were recorded as Scartichthys gigas/viridis. The diver swam calmly along the sampling unit, while observing from the ground up to the water surface, which, in the case of the experimental plots, included the canopy level. The spatial distribution of the fish species was categorised according to Nuñez and Vásquez (1987) in (1) rock (fishes associated directly with rock substratum feeding and/or settling on it), (2) macroalgae (fishes associated directly feeding and/or settling on macroalgae) and (3) water column (fishes above rock or macroalgae) (the fourth category 'sand' did not exist at the study site). The permanence of the recorded fish species was classified according to Vargas and Sielfeld (1997) as 'resident species', which are present throughout the year; 'seasonal visitors', which are present seasonally; and 'occasional species', which show no seasonal pattern of occurrence but cannot be found throughout the year.

During the dive surveys, benthic biota was systematically assessed. Within each experimental and control unit, one scientific scuba diver, trained in identifying the local benthic biota, put hazardly three times (three replicates) a square of $1 \mathrm{~m}$ side length. The diver recorded (i) the percentage cover of the respective macroalgal species and (ii) the number of macrobenthic invertebrates $(>1 \mathrm{~cm})$ enframed. Individual 
epibenthic organisms were identified visually to the lowest level possible, which was commonly species level.

\section{Statistical analysis}

Univariate biodiversity indices, such as species richness (Margalef) $(d=(S-1) / \log (N))$, Shannon-Wiener Index $\left(H^{\prime}, \log e\right)$ and Pielou's evenness $\left(J^{\prime}\right)$, were calculated using the software package PRIMER v6 (Clarke and Gorley 2006) and used to assess the fish assemblages of the experimental and control plots.

Multivariate statistic was applied to perform community analyses using abundance data of the treatment and control plots (obtained from the dive surveys), again using the software package PRIMER v6 with its PERMANOVA+ add-on (Clarke and Gorley 2006; Anderson et al. 2008). A similarity matrix was calculated by means of Euclidean distances of the fish abundance data. This similarity matrix was used in a PERMANOVA to pairwise compare fish assemblages of the forested versus the control plots. The Monte Carlo option of the PERMANOVA routine was used to ensure 9999 permutations. As a significant relation between the fish assemblages of the two factors was detected, pairwise tests were performed to examine differences between plots.

Abundance values of fish, algae and invertebrate species were square root transformed to reduce the effect of high variation among taxa. These transformed values were used in a two-way SIMPER test (Clarke and Warwick 1994) to establish the percent dissimilarity across plots and to find out which species were the primary contributors to these differences. Mean abundance values of fish in relation to their spatial distribution, algae and invertebrates were arranged in three matrices. Again, data were square root transformed to reduce the effect of high variation among taxa. Between-stations similarities were calculated using the Bray-Curtis Index (Bray and Curtis 1957) and group average linkage. The resemblance pattern in the similarity matrices was visualised using 2-D non-metric multi-dimensional scaling (nmMDS) plots. The stations were grouped based on a cluster and SIMPROF analysis (Clarke and Gorley 2006). To check for interactions, RELATE tests (Clarke and Warwick 1994) were performed to examine correlations between the fish and (a) the invertebrate, (b) the algae (excluding the forested M. pyrifera) and (c) the combined benthic community (invertebrates + algae excluding the forested M. pyrifera) similarity matrices based on the abundance data. In case a significant correlation was evident, BEST tests (Clarke and Gorley 2006) were performed to correlate two similarity matrices. In this case, one matrix is considered as the 'explained' or dependent matrix and the other as the 'explanatory' or independent matrix. The BEST procedure examines the variables (taxa) from the explanatory matrix (here invertebrate, algae [excluding the forested M. pyrifera] or combined benthic community [invertebrates
+ algae excluding the forested $M$. pyrifera $]$ ) one at a time, then pairs of variables, triplets and so on (Clarke et al. 2008). Thereafter, BEST identifies the variables that 'best explain' the pattern of the explained matrix.

\section{Results}

\section{Fish species abundance, fish community composition and diversity}

A total of six fish species (Perciformes, Actinopterygii) from six families was present during the study period, with five species (the herbivorous Scartichthys gigas/viridis and the carnivorous Chromis crusma, Cheilodactylus variegatus, Halichoeres dispilus and Helcogrammoides chilensis) occurring at the control plots (mean species number per plot, $0.7 \pm 0.7$; range, $0-3$ ) and all six (including the omnivorous Isacia conceptionis) at the forested plots (mean species number per plot $=1.8 \pm 1.2$, range $=0-4)($ data available at Villegas et al. 2018a).

The resident fish species Scartichthys gigas/viridis, Chromis crusma, Cheilodactylus variegatus and Isacia conceptionis numerically dominated the fish assemblages of the experimental kelp patches (Fig. 2), Halichoeres dispilus, and Helcogrammoides chilensis only occurred occasionally.

Fishes were significantly more abundant at the forested plots (mean $=3.71$ ind.$/ 9 \mathrm{~m}^{2}$ ) compared to the controls without kelp (mean $=0.86$ ind. $/ 9 \mathrm{~m}^{2}$ ) (Mann-Whitney $U$ test, $Z=3.82, p=$ 0.0002; Fig. 2). The PERMANOVA main test also indicates that there are significant differences in the fish communities among the forested and control plots $(P($ perm $)=0.0001$; $P(\mathrm{MC})=0.0004)$. At an Euclidean distance of 2, the cluster analyses identified one mixed group with 28 samples from control and experimental plots, while the remaining 14 were distributed in homogeneous groups with samples from just

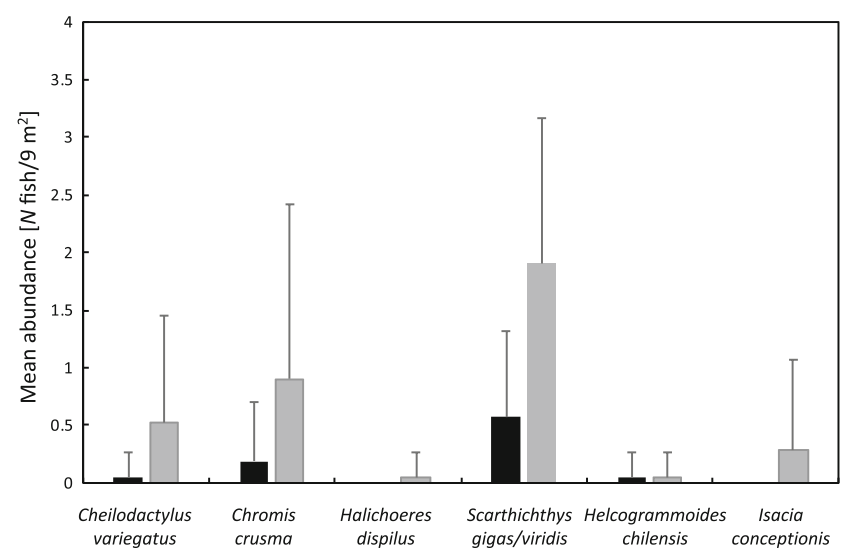

Fig. 2 Mean abundance of all six fish species $\left(N\right.$ fish $\left./ 9 \mathrm{~m}^{2}\right)$ recorded in experimental (forested) and control (barren) plots. The values correspond to mean $\pm \mathrm{SD}(n=15)$; grey $=$ forested plot, black $=$ control plot 
experimental plots (Fig. 3). Fish species richness and diversity were higher in forested plots (mean $d=0.73, H^{\prime}=0.47$, $\left.J^{\prime}=0.92\right)$ compared to control plots $\left(d=0.36, H^{\prime}=0.05\right)$.

The algal inventory and coverage did not significantly differ between the treatments and controls. Algae (excluding the transplanted M. pyrifera specimens) covered $21.33 \% \pm 15.02 \%$ of the experimental and $18.14 \% \pm 14.27 \%$ of the control plots. The following algal species were recorded: Asparagopsis armata (coverage: experimental $0.57 \% \pm 1.03 \%$, control $0.86 \% \pm 1.85 \%$ ), Gelidium chilense (coverage: experimental $13.57 \% \pm 13.28 \%$, control $9.33 \% \pm 11.52 \%$ ), Glossophora kunthii (coverage: experimental $0.05 \% \pm 0.22 \%$, control $0.48 \% \pm 1.29 \%$ ), Halopteris hordacea (coverage: experimental $1.57 \% \pm 2.13 \%$, control $1.67 \% \pm 2.31 \%$ ), Rhodymenia cf. corallina (coverage: experimental $0.14 \% \pm 0.48 \%$, control $0.05 \% \pm 0.22 \%$ ), Ulva rigida (coverage: experimental $2.62 \%$ $\pm 2.71 \%$, control $1.57 \% \pm 1.57 \%$ ) and an unidentified Chlorophyta (coverage: experimental $2.76 \% \pm 3.56 \%$, control $4.05 \% \pm 6.09 \%$ ) (data available at Villegas et al. 2018b).

Echinoderms (Heliaster helianthus, Luidia magellanica, Stichaster striatus, Holothuroidea, Loxechinus albus) comprised 33\%, crustaceans (Cancer edwardsii, Cancer setosus, Pagurus edwardsii, Taliepus dentatus) 27\%, gastropods (Crassilabrum crassilabrum, Fissurella latimarginata, Tegula tridentata) 20\%, anthozoans (Anemonia alicemartinae, Anthothoe chilensis) $13 \%$ and ascidians (Pyura chilensis) $7 \%$ of the 14 known species and additional one family not further identified. Concerning the number of individuals, ascidians made up $48 \%$ of the specimens, anthozoans $36 \%$, echinoderms $14 \%$ and crustaceans and gastropods $1 \%$ each (data available at Villegas et al. 2018c).

As neither the algal community (excluding the transplanted M. pyrifera specimens) nor the invertebrate community was significantly different between the forested and the control plots, the only contrast was the significant difference in the forested $M$. pyrifera (RELATE test Spearman rank correlation: $\rho=0.102 ; p=0.012$ ).

\section{Microhabitats used by fishes}

Spatial distribution of fish abundances differed significantly between experimental and control plots (Mann-Whitney $U$ test: rock $Z=3.69, p=0.0003$; water column $Z=2.23, p=$ 0.049 ; macroalgae $Z=2.67, p=0.06$; Fig. 4). Fishes were more abundant within experimental kelp patches than at the control plot without kelp (3.71 fish $/ 9 \mathrm{~m}^{2}$ versus $1.14 \mathrm{fish} / 9 \mathrm{~m}^{2}$, respectively), and fish abundance on rocks of the kelp patches was higher than the abundance on plots with rocks without $\operatorname{kelp~(2.19~fish~} / 9 \mathrm{~m}^{2}$ and $0.62 \mathrm{fish} / 9 \mathrm{~m}^{2}$, respectively) (Fig. 4).

Similarly, S. gigas/viridis showed significantly higher abundance on rocks of the forested plots in comparison to rocks of the control plots (Mann-Whitney $U$ test: $p=$ 0.0008). The relative importance of the rocky habitat with macroalgae was slightly higher than the importance of rocky habitats on grounds without kelp (59\% and 54\%, respectively), but the importance of the water column as habitat was inverse (27\% to $46 \%$, respectively) (Fig. 4).

The nmMDS revealed different distributions of the fish species in the forested areas: S. gigas/viridis was more abundant on rocks (Fig. 5a) and C. variegatus in macroalgae (Fig. 5b). C. crusma and I. conceptionis preferred the water column (Fig. 5c, d).

The entire algal community (not including the transplanted M. pyrifera) correlates significantly with the fish community (RELATE test Spearman rank correlation: $\rho=0.444 ; p=$ 0.006). The algal species that best explain the fish variation are Gelidium chilense and Ulva rigida (Spearman rank correlation: $\rho=0.567 ; p=0.009$ ).

During the experiment, kelp patches were exposed to constant natural swell and wave action. Some blades were lost and
Fig. 3 Non-metric multidimensional scaling (nmMDS) plot visualising the amongstations resemblance pattern of the fish fauna identified in experimental (e, forested) and control (c, barren) plots recorded during dive surveys between 15 February 2007 and 11 April 2007. The pattern is based on the Euclidean distance calculated from abundance data. Grouping obtained from cluster and SIMPROF analysis is shown; line indicates a Euclidean distance of 2, note: Some points of replicates overlap in the 2-D projection
Resemblance: D1 Euclidean distance

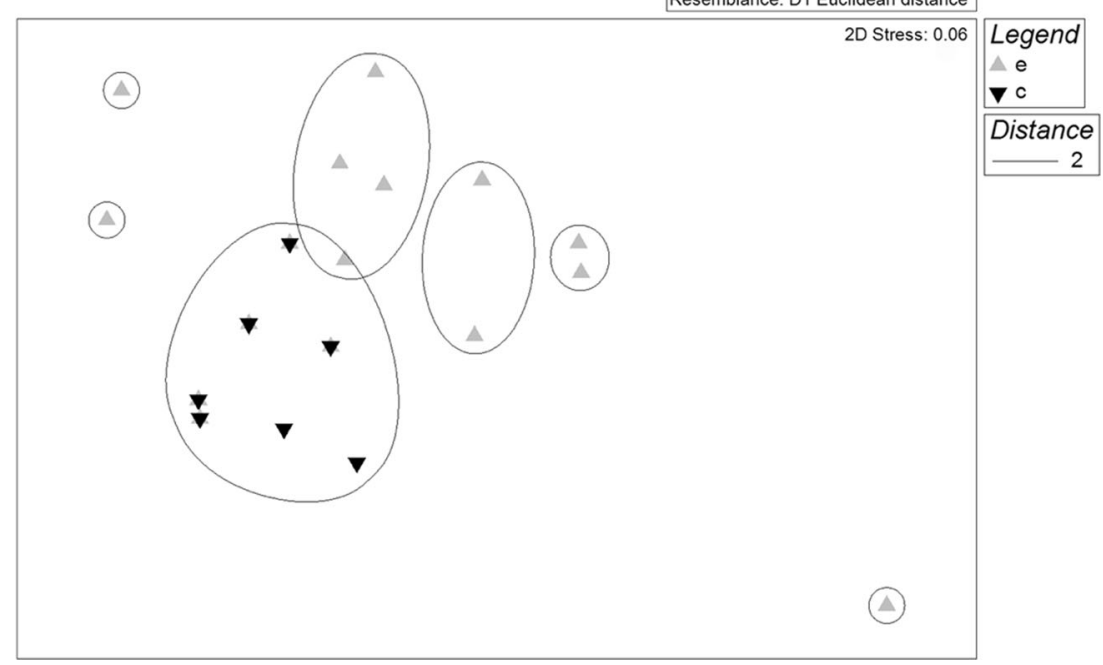




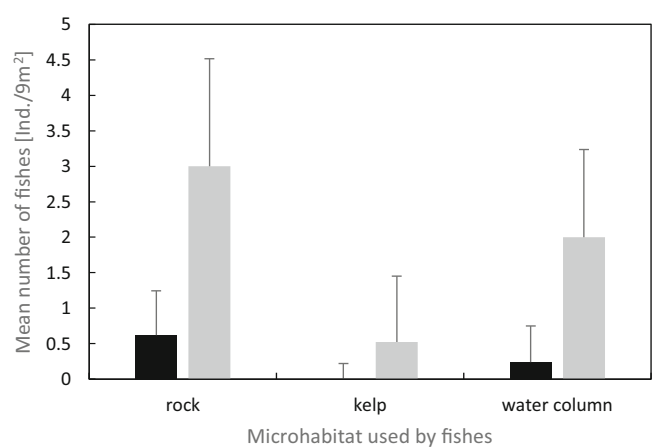

Fig. 4 Spatial distribution of fish (number of individuals $/ 9 \mathrm{~m}^{2}$ ) in the different habitat types for each experimental (forested) and control (barren) area. The values correspond to mean $\pm \mathrm{SD}$; grey $=$ forested plot, black $=$ control plot

plants detached. The number of fishes was positively correlated with the declining kelp abundance (Spearman index: $r=$ $0.964, p=0.00045$; Fig. 6). The most abundant fish species showed different responses to the changes in the experimental areas (Fig. 7): while C. variegatus and I. conceptionis declined in abundance, that of $S$. gigas/viridis remained constant.

\section{Fish and associated biota}

The invertebrate community (data available at Villegas et al. 2018c) correlates significantly with the fish community (RELATE test Spearman rank correlation: $\rho=0.519 ; p=$ 0.003). The invertebrates that best explain the fish variation are the actinians A. alicemartinae and A. chilensis, the asteroid $H$. helianthus, the sea urchin L. albus and the hermit crab P. edwardsii (Spearman rank correlation: $\rho=0.581 ; p=0.003$ ).

The entire benthic community (invertebrates and algae) also correlates significantly with the fish community. Species that best explain the fish variation are the algae
Glossophora kunthii and Ulva rigida, the actinians Anemonia alicemartinae and Anthothoe chilensis, the asteroid Heliaster helianthus and the hermit crab Pagurus edwardsii (Spearman rank correlation: $\rho=0.658 ; p=$ $0.002)$. No significant results were found when correlating either invertebrate species or algal species with the fish community (all $p$ values were $>0.09$ ).

\section{Discussion}

\section{Fish community composition and diversity related to forested versus control plots}

In temperate regions, reef fishes are frequently associated with macroalgae (e.g. Holbrook et al. 1990; Levin and Hay 1996; Pérez-Matus et al. 2007, 2012; Sielfeld et al. 2010; Miller et al. 2018; Witman and Lamb 2018). Studies from the Southern and Northern Hemisphere (New Zealand, California, Canada and New England [USA]) indicate that kelp density is often reflected in reef fish abundance (e.g. Jones 1984a, b; DeMartini and Roberts 1990; Holbrook et al. 1990; Schmitt and Holbrook 1990; Carr 1991, 1994; Levin 1991, 1993, 1994; Anderson 1994; Anderson and Millar 2004; Trebilco et al. 2015; Witman and Lamb 2018). The present in situ experiment carried out in the wave-swept rocky subtidal zone of northern Chile showed that several parameters of the fish assemblage significantly increased (fish abundance increased more than fourfold, species richness doubled and fish diversity increased by factor 9.4), when areas formerly lacking kelp were forested with $M$. pyrifera. Similar abundance of fish species was observed in a neighbouring $M$. pyrifera kelp bed at Caleta Chipana between 2005 and 2007 (Villegas et al. 2018d, e, f). However, the kelp bed shelters eight species of
Fig. 5 Non-metric multidimensional scaling (nmMDS) plots showing the spatial distribution in experimental (forested, E) and control (barren, C) areas and different habitats $(\mathrm{R}=$ rock, $\mathrm{M}=$ macroalgae, $\mathrm{W}=$ water column) of the most abundant fish species. a Scartichthys gigas/viridis. $\mathbf{b}$ C. variegatus. c C. crusma. $\mathbf{d}$ I. conceptionis. $($ Stress $=0)$
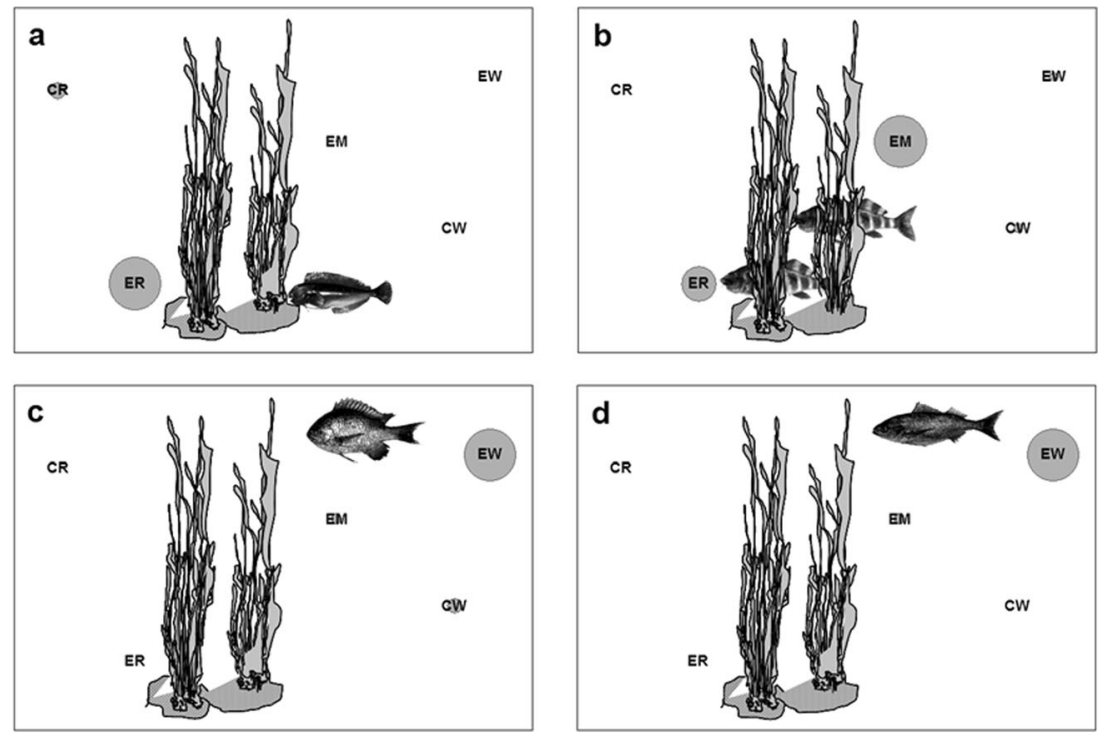


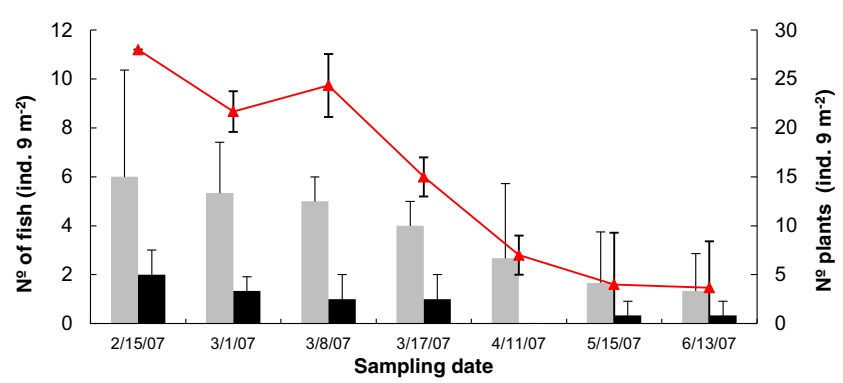

Fig. 6 Relation between the mean number of fishes and the number of plants in the experimental area, between 15 February 2007 and 13 June 2007; grey $=$ forested plot, black $=$ control plot, red line $=$ number of Macrocystis pyrifera plants in forested barren ground area

which five (Chromis crusma, Cheilodactylus variegatus, Isacia conceptionis, Scartichthys gigas/viridis and Halichoeres dispilus) of the six species recorded during this study were also included in the eight species observed in the neighbouring M. pyrifera kelp bed. Helcogrammoides chilensis, which was recorded in the forested plots, occurred on ground without kelp in the former study (Villegas et al. 2018d, e, f). This is in agreement with the data of Pérez-Matus et al. (2016), who showed that the related triplefin blenny Helcogrammoides cunninghami avoids kelp beds and prefers filamentous understory algae, where the predation rate is halved. In line, cryptobenthic Mediterranean Blenniidae are more abundant in 'bushland' algae versus arborescent forests (Cheminée et al. 2017).

Scarce species e.g. Aplodactylus punctatus (one record, $1200 \mathrm{~m}^{-2}$ ), the resident species Girella laevifrons (six records, $1200 \mathrm{~m}^{-2}$ ) and the seasonal species Labrisomus phillippii (four records, $1200 \mathrm{~m}^{-2}$ ), Nexilosus latifrons (eight records, $1200 \mathrm{~m}^{-2}$ ) and Paralabrax humeralis (nine records, $1200 \mathrm{~m}^{-2}$ ) were not observed in the forested plots. This may, however, be a matter of sample effort as the present study only covered $15.8 \%$ of the total sampling area of the former study (Villegas et al. 2018d, e, f). Temporal or seasonal variability may also partly explain the differences, as Aplodactylus punctatus and Girella laevifrons were only recorded in December 2005 during the former study (Villegas et al. 2018d, e, f). Furthermore, Ruz et al. (2018) revealed strong interactions of the former fish with the kelp Lessonia trabeculata, which also forms beds at the present study site (Villegas et al. 2008). Indeed, the diet of adult Aplodactylus punctatus is composed of $75 \% \mathrm{~L}$. trabeculata and $10 \%$ other algae (i.e. Gelidium chilense, Ulva rigida and corallines) (Benavides et al. 1994; Pérez-Matus et al. 2012), which may explain its rarity in the M. pyrifera kelp bed.

Chromis crusma, Cheilodactylus variegatus and Isacia conceptionis were also common at two neighbouring M. pyrifera kelp beds at Caleta San Marcos $\left(21^{\circ} 32^{\prime} \mathrm{S}, 70^{\circ}\right.$ $10^{\prime} \mathrm{W}$; Godoy 2000) and Rio Seco $\left(21^{\circ} 00^{\prime} \mathrm{S}, 70^{\circ} 10^{\prime} \mathrm{W}\right.$; Pérez-Matus et al. 2007, 2012). In the former Blennioidei, probably Scartichthys gigas/viridis were also recorded (Godoy
2000). They are common in kelp beds (Angel and Ojeda 2001; Pérez-Matus et al. 2007, 2012, 2017) and rocky intertidal environments (Varas and Ojeda 1990; Muñoz and Ojeda 2000).

\section{Invertebrate community composition}

The invertebrate epifauna recorded during the dive surveys (15 taxa) resembled that recorded by Villegas et al. (2008) from the neighbouring $M$. pyrifera kelp bed off Chipana. In the present study, the crab Metacarcinus edwardsii, the hermit crab Pagurus edwardsii and an unidentified holothurian were also found in the forested and the sea star Luidia magellanica on the non-kelp plots. The gastropod Concholepas concholepas, the brachyuran crabs Cancer coronatus and Paraxanthus barbiger and the black sea urchin Tetrapygus niger occurred on plots without kelp of the former study, but were absent in this study. This macrobenthos is also associated with holdfasts elsewhere in Chile (Godoy 2000; Vásquez et al. 2001) and is characteristic of rocky substrates within northern and central Chilean M. integrifolia and L. trabeculata kelp beds (Vásquez 1993; Stotz et al. 2003; Graham et al. 2007).

\section{Microhabitats used by fish}

Different responses of the reef fish species to the forested kelp were observed. These differences may reflect specific fish species interactions with $M$. pyrifera, considering shelter and habitat for prey. The spatial distribution of fish between experimental and control plots was significantly different.

Abundances of the demersal fish Scartichthys gigas/ viridis were significantly higher (more than threefold) on rocks of the forested plots compared to rocks of the plots without kelp. Scartichthys viridis consumes almost exclusively macroalgae. The sheet-like green macroalgae Ulva rigida and Ulva linza were the main items consumed by young individuals at the central Chilean coast, and the tough branching red macroalga Gelidium chilense increased in importance during ontogeny (Muñoz and Ojeda 2000). Ulva rigida (55 versus 32 records) and the numerically most abundant Gelidium chilense (285 versus 195 records) were more abundant in the forested compared to the control plots, which may explain the increased abundance of Blennioidei in the forested plots. Ephemeral algae such as Ulva spp. together with Asparagopsis armata are common in the kelp understorey (Pérez-Matus et al. 2007) and were also recorded in the present area (Pinto 1989; Romero 2003). The present RELATE analyses revealed a significant correlation between the algal and fish communities. Indeed, Gelidium chilense and Ulva rigida are the two algae that best explain the fish variation in Chipana.

The morwong, Cheilodactylus variegatus, was recorded on rocks and between the $M$. pyrifera stipes of the forested plots but was absent on rocks of the control plots. It was also 
Fig. 7 Abundances of the dominating fish species present in the experimental (forested) areas between 15 February 2007 and 13 June 2007. a Scartichthys gigas/ viridis. b $C$. variegatus. c

C. crusma. d I. conceptionis
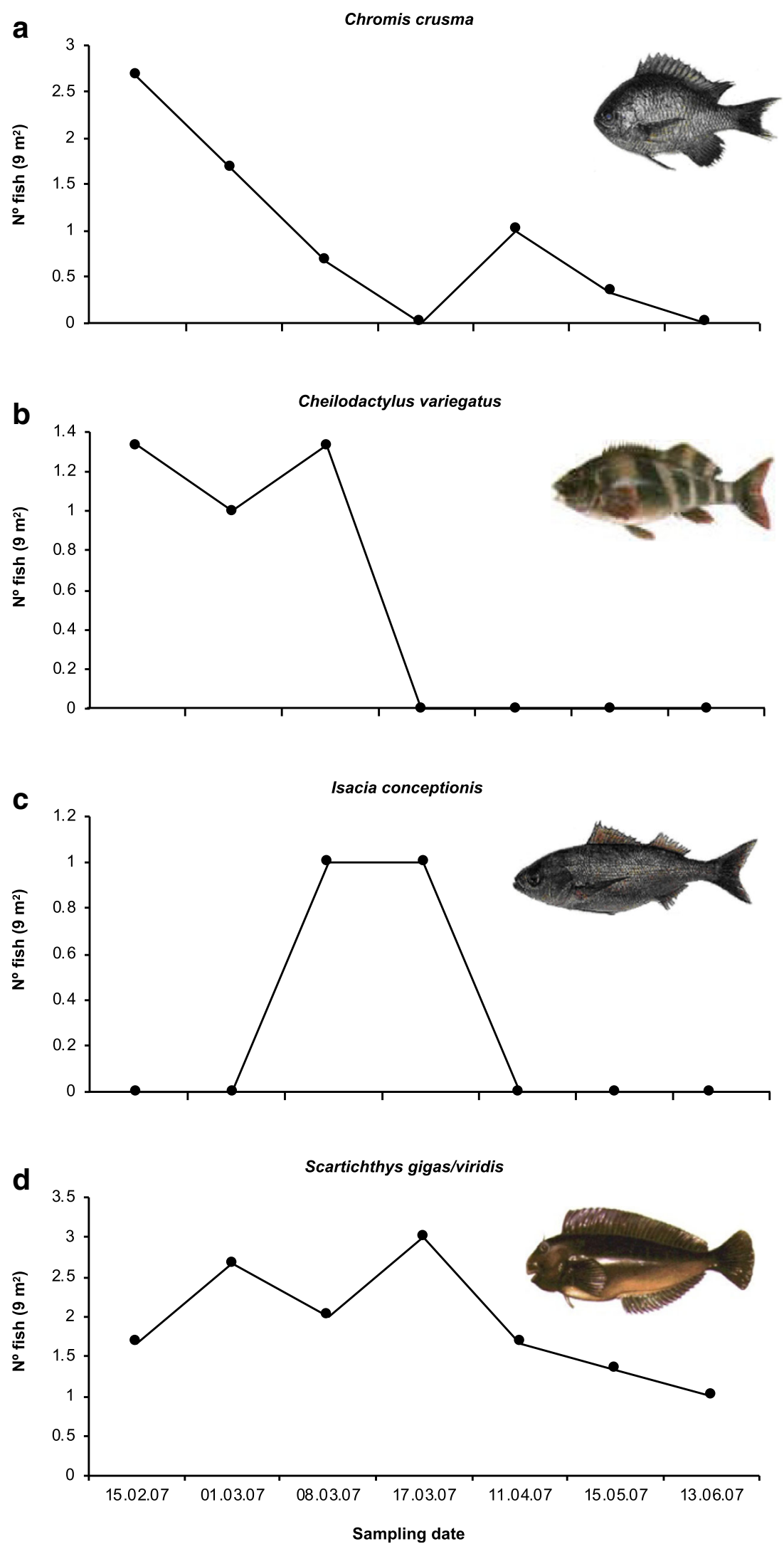

abundant in the neighbouring $M$. pyrifera kelp bed of Rio Seco, where it represents almost half of the fish assemblage and is related to the occurrence of turf algae and sea stars, S. striatus (Pérez-Matus et al. 2007, 2012), which were also 
present in the forested plots. The former study revealed that Cheilodactylus variegatus preys on decapod crustaceans and molluscs. Metacarcinus edwardsii was exclusively recorded in the forested plots, and Cancer setosus was numerically more frequent at these plots. This also holds true for the keyhole limpet Fissurella latimarginata.

The reason why the invertebrate community correlates significantly with the fish community is presumably the cooccurrence in the preferred habitat. Three of the carnivorous benthic invertebrates (i.e. Anemonia alicemartinae and Anthothoe chilensis, Pagurus sp.) that best explain the fish variation share food resources with fish species (Vásquez 1993; for Anemonia alicemartinae, Häussermann and Försterra 2001) and are more abundant in the forested plots.

The red sea urchin Loxechinus albus was significantly more abundant on non-kelp plots compared to the transplanted M. pyrifera patches as also found by Villegas et al. (2008). Vásquez et al. (1984) never found Loxechinus albus inside the holdfasts of $M$. pyrifera. Although over-grazing of kelp forests by sea urchins may lead to a considerable loss of biogenic habitat, in extreme cases causing shifts from structurally complex habitat to 'barrens' (e.g. Filbee-Dexter and Scheibling 2014; Perreault et al. 2014; Ling et al. 2015), it is unlikely that Loxechinus albus controls the M. pyrifera distribution off northern Chile. Castilla and Moreno (1982) showed that this species mainly consumes drifting fronds and has no significant effect on recruitment or survival of juvenile M. pyrifera. Furthermore, Santelices and Ojeda (1984) showed that the canopy is more likely to determine $M$. pyrifera recruitment than the presence of grazers. Thus, the correlation between the present fish community and Loxechinus albus may simply reflect the habitat differences between the forested plots and the plots without kelp and may not be caused by the presence of Loxechinus albus. The latter is more abundant in barrens, as shown by Villegas et al. (2008).

\section{Structural complexity}

As neither the algal community (excluding the transplanted M. pyrifera specimens) nor the invertebrate community significantly changed between the forested and the control plots (yet) during the 8 -week study period, but the algal community (without the transplants) correlates significantly with the fish community, the observed significant changes in fish abundance between the experimental and control plots may also be allocated to the increased structural complexity provided by the forested M. pyrifera (e.g. Trebilco et al. 2015). The morphological features of transplanted M. pyrifera are habitat specific as demonstrated by Brostoff (1988) and Druehl and Kemp (1982); thus, changes in respect to the structure within the neighbouring kelp beds are unlikely.
Effects of the transplanted kelp are particularly obvious for C. crusma (19 sightings in the forested versus 4 sightings in the control plots), C. variegatus (11 sightings in the forested versus 1 sighting in the control plots), S. gigas/viridis (40 sightings in the forested versus 12 sightings in the control plots) and I. conceptionis (6 sightings in the forested versus no sighting in the control plots). The transplanted kelp also has far-reaching effects on the surroundings, which is reflected in the observation that there was a fourfold increase in the number of fish using the interspace free water between the kelp plants in comparison with the water column of the control plots.

Two explanations are suggested for the increased fish abundance of the forested plots. The large arborescent form of M. pyrifera extends from the seafloor to the water surface, where it develops floating canopies. Thus, fishes passing by in any water depth may be attracted by the structure and stay in the area (Levin and Hay 1996). Some specimens of I. conceptionis even followed the M. pyrifera plants while being transported from the kelp bed to the experimental plot (Laudien et al. 2018). The different storeys (holdfast, stipes, canopy) also provide different microhabitats, which may be used by fishes with different ecological niches (Vanella et al. 2007); e.g. S. gigas/viridis prefers the holdfast storey and C. variegatus the holdfast and stipes, while C. crusma and I. conceptionis favour the free water. Elsewhere in temperate waters of the Northern Hemisphere, the changed abundance and structure of different macroalgal species also showed significant effects on fish abundance and richness (Levin and Hay 1996; Anderson and Millar 2004; Cheminée et al. 2017).

The declining $M$. pyrifera abundance significantly affected the fish abundance. However, the relation between kelp abundance and fish abundance differed among species. While the abundance of $C$. variegatus and $I$. conceptionis decreased with declining $M$. pyrifera abundance, the response of $S$. gigas/ viridis differed and remained equally abundant, even when only seven of the originally 28 transferred plants were left in the forested plots. This suggests that above a threshold abundance of $M$. pyrifera, an increase in kelp abundance does not affect the abundance of the giant blenny. The abundance of the turf algae may not have reflected the reduced kelp abundance. Similarly, distinct fish species showed different thresholds for macroalgal abundances in the South Atlantic Bight (Levin and Hay 1996). Additionally, this demersal fish may depend on the understorey rather than on the kelp itself, which may not decrease in equal proportions as the abundance of M. pyrifera.

Juvenile specimens of Chromis crusma and Cheilodactylus variegatus were observed in forested plots, while the control plots were exclusively used by adults of these two species. Several studies indicate that different size classes of reef fishes respond distinctively to modified kelp habitats. Generally, small fishes, which are dependent on the algal-generated structural complexity, occur in kelp beds, whereas larger 
fishes that are becoming increasingly independent of this structure may commonly be found over urchin barrens (Choat and Ayling 1987; Holbrook et al. 1990; Levin 1993). Two strategies were observed, either selective settlement in habitats with high structural complexity (Jones 1984b; Levin 1993) or random settlement followed by strong predation pressure in less complex habitats (Connell and Jones 1991). Thus, predation may restrict new recruits and juvenile fish to kelp beds, where structural complexity is high. This may determine the subsequent adult standing stock (e.g. Doherty and Fowler 1994). The extension of $M$. pyrifera kelp beds may represent the ecosystem capacity for adult reef fish populations.

\section{Harvesting and foresting}

Harvesting (Vásquez et al. 2012; Vega et al. 2014; Westermeier et al. 2016) and/or natural impacts, such as EN (Vega et al. 2005; Vásquez et al. 2006; Graham et al. 2007; Villegas et al. 2008), may require the need to design restoration strategies for $M$. pyrifera kelp beds although $M$. pyrifera may naturally colonise former locations entirely. However, natural propagation may be a long process due to the diplohaplontic, heteromorphic life cycle of this kelp species. As typical of Laminariales, its motile, flagellated zoospores are released into the water. The zoospores are viable for a few hours and are, therefore, only capable of short distance dispersal before settlement to suitable substrate (but see Macaya et al. 2005 and Ruz et al. 2018 for a different species of the Laminariales). Restoration can speed up this process (Hernández-Carmona et al. 2000; Correa et al. 2006; Westermeier et al. 2016) although the present study indicates that the appropriate method should be selected.

Grounds without kelp were forested by transferring M. pyrifera-colonising boulders, which were collected from the center of a neighbouring M. pyrifera kelp bed. This was only semi successful as several of the transplanted plants did not withstand the surge during storm events and detached. In general, beds of giant kelp reduce water current velocity (Stachowicz 2001) and thus facilitate congeneric and many other species less tolerant of disturbing current conditions. In Laminariales, such as M. pyrifera, holdfast structures (i.e. intertwined haptera, which form a complex of fine branches) vary markedly between plants subjected to different environmental conditions (Sjøtun and Fredriksen 1995). Particularly, in response to gradients in wave exposure or current flow, the biomass and internal volume of holdfasts may more than double along a wave exposure gradient (Teagle et al. 2017). Other successful studies conducted elsewhere were also based on the transfer of seaweed-covered rocks or rock fragments (e.g. Ho 1984; Buschmann et al. 1997; Blanchette et al. 2002; Marsden et al. 2003), thereafter gluing them to the substratum or by fixing kelp to the rock (Correa et al. 2006; Westermeier et al. 2014b). Future studies should transfer seaweeds grown under more exposed conditions with stronger holdfasts developed as a result of adaptation to the current regime. Alternatively, mature sporophylls, juvenile plants or holdfast fragments may be transferred (Westermeier et al. 2014b, 2016), so that plants may adapt while growing and drag is increasing or plants may be fixed by using a plastic net device anchored with stainless steel bolts to the rock (Correa et al. 2006). This will yield adults adapted to the local current conditions, which may rapidly induce fertile plants as a close-by source of propagules (Rice et al. 1989; Hernández-Carmona et al. 2000; Westermeier et al. 2016).

Further experiments should examine habitat effects of different kelp species, morphotypes, and artificial structures (e.g. Carr and Reed 2015) to reveal the basic knowledge for management advice during harvest programs of kelp, and after kelp mass mortalities associated with EN.

Acknowledgements We thank Jadhiel Godoy, Daniel Carstensen and José Alberto Vélez who assisted during diving excursions in Chipana. We also express our thanks to Urbano Castillo for providing the logistics in the field and to the Sindicato de Buzos Mariscadores de Caleta Chipana for the permission to work in their management area. Thank you to Alexander Buschmann, who designed Fig. 1, and Renate Kuchta, who helped with Figs. 5 and 7. Ruth Alheit assisted with the English editing.

Funding information This study was financed and conducted in the frame of the EU project CENSOR (Climate Variability and El Niño Southern Oscillation: Implications for Natural Resources and Management, contract 511071), and the Programa Bicentenario de Ciencia y Tecnología CONICYT-CENSOR-RUE 02.

Open Access This article is distributed under the terms of the Creative Commons Attribution 4.0 International License (http:// creativecommons.org/licenses/by/4.0/), which permits unrestricted use, distribution, and reproduction in any medium, provided you give appropriate credit to the original author(s) and the source, provide a link to the Creative Commons license, and indicate if changes were made.

\section{References}

Angel A, Ojeda FP (2001) Structure and trophic organization of subtidal fish assemblages on the northern Chilean coast: the effect of the habitat complexity. Mar Ecol Prog Ser 217:81-91

Anderson TW (1994) Role of macroalgal structure in the distribution and abundance of a temperate reef fish. Mar Ecol Prog Ser 11:279-290

Anderson MJ, Millar RB (2004) Spatial variation and effects of habitat on temperate reef fish assemblages in northeastern New Zealand. J Exp Mar Biol Ecol 305:191-221

Anderson MJ, Gorley RN, Clarke KR (2008) PERMANOVA+ for PRIMER: guide to software and statistical methods. PRIMERE, Plymouth

Aguilera V, Escribano R, Herrera L (2009) High frequency responses of nanoplankton and microplankton to wind-driven upwelling off northern Chile. J Mar Syst 78:124-135 
Arntz WE, Gallardo VA, Gutiérrez D, Isla E, Levin LA, Mendo J, Neira C, Rowe GT, Tarazona J, Wolff M (2006) El Niño and similar perturbation effects on the benthos of the Humboldt, California, and Benguela Current upwelling ecosystems. Adv Geosci 6:234-265

Benavides AG, Cancino JM, Ojeda FP (1994) Ontogenetic changes in gut dimensions and macroalgal digestibility in the marine herbivorous fish, Aplodactylus punctatus. Funct Ecol 8:46-51

Berrios VL, Vargas M (2000) Estructura del ensamble de peces intermareales de la costa rocosa del norte de Chile. Rev Biol Mar Oceanogr 35:73-81

Berrios VL, Vargas M (2004) Estructura trófica de la asociación de peces intermareales de la costa norte de Chile. Rev Biol Trop 52:201-212

Blanchette CA, Miner BG, Gaines SD (2002) Geographic variability in form, size and survival of Egregia menziesii around Point Concepción, California. Mar Ecol Prog Ser 239:69-82

Bray JR, Curtis JT (1957) An ordination of upland forest communities of southern Wisconsin. Ecol Monogr 27:325-349

Brostoff WN (1988) Taxonomic studies of Macrocystis pyrifera (L.) C. Agardh (Phaeophyta) in Southern California: holdfasts and basal stipes. Aquat Bot 31:289-305

Buschmann A, Correa JA, Beltrán J, Retamales C (1997) Determinants of disease expression and survival of infected individuals in wild populations of Mazzaella laminarioides (Rhodophyta) in central and southern Chile. Mar Ecol Prog Ser 154:269-280

Buschmann AH, Vásquez JA, Osorio P, Reyes E, Filún L, HernándezGonzález MC, Vega A (2004) The effect of water movement, temperature and salinity on abundance and reproductive patterns of Macrocystis spp. (Phaeophyta) at different latitudes in Chile. Mar Biol 145:849-862

Buschmann AH, Prescott S, Potin P, Faygeron S, Vásquez JA, Camus C, Infante J, Hernandez-Gonzalez MC, Guyerrez A, Varela DA (2014) The status of kelp exploitation and marine agronomy, with emphasis on Macrocystis pyrifera, in Chile. Adv Bot Res 71:161-188

Cancino J, Santelices B (1981) The ecological importance of kelp-like holdfasts as habitat of invertebrates in Central Chile. II. Factors affecting community organization. In: Levring, T (ed.), Proceedings of the International Seaweed Symposium 10: 241-246

Carr MH (1991) Habitat selection and recruitment of an assemblage of temperate zone reef fishes. J Exp Mar Biol Ecol 146:113-137

Carr MH (1994) Effects of macroalgal dynamics on recruitment of a temperate reef fish. Ecology 75:1320-1333

Carr MH, Reed DC (2015) Shallow rocky reefs and kelp forests. Ecosystems of California. University of California Press, Berkeley, pp 311-336

Castilla JC, Moreno CA (1982) Sea urchins and Macrocystis pyrifera: experimental test of their ecological relations in southern Chile. In: Lawrence JM (ed) International Echinoderms Conference. A.A. Balkema, Rotterdam, pp 257-263

Cheminée A, Pastor J, Bianchimani O, Thiriet P, Sala E, Cottalorda JM, Dominici JM, Lejeune P, Francour P (2017) Juvenile fish assemblages in temperate rocky reefs are shaped by the presence of macroalgae canopy and its three-dimensional structure. Sci Rep 7:1-11

Clarke KR, Gorley RN (2006) Primer V6: user manual/tutorial. PRIMER-E, Plymouth, p 192

Clarke K, Warwick R (1994) Changes in marine communities: an approach to statistical analysis and interpretation. Natural Environmental Research Council, Plymouth, p 144

Clarke KR, Somerfield PJ, Gorley RN (2008) Testing null hypotheses in exploratory community analyses: similarity profiles and biotaenvironment linkage. J Exp Mar Biol Ecol 320:11-27

Choat JH, Ayling AM (1987) The relationship between habitat structure and fish faunas on New Zealand reefs. J Exp Mar Biol Ecol 110: $257-284$
CONAMA (2008) Sitios prioritarios. In: Rovira J, Ugalde J, Stutzin M (Eds.) Biodiversidad de Chile: Patrimonio y Desafios (Seccond Edition). Comisión Nacional del Medio Ambiente (CONAMA), pp 593-595

Connell SD, Jones GP (1991) The influence of habitat complexity on postrecruitment processes in a temperate reef fish population. $\mathrm{J}$ Exp Mar Biol Ecol 151:271-294

Correa JA, Lagos NA, Medina MH, Castilla JC, Cerda M, Ramírez M, Martínez E, Faugeron S, Andrade S, Pinto R, Contreras L (2006) Experimental transplants of the large kelp Lessonia nigrescens (Phaeophyceae) in high-energy wave exposed rocky intertidal habitats of northern Chile: experimental, restoration and management implications. J Exp Mar Biol Ecol 335:13-18

Dayton P (1985) Ecology of kelp communities. Annu Rev Ecol Syst 16: 215-245

Dayton PK, Tegner MJ (1989) Bottoms beneath troubled waters: benthic impacts of the 1982-1984 El Niño in the temperate zone. In: Glynn PW (ed) Global consequences of the 1982-83 El Niño-Southern Oscillation. Elsevier Sciences, Miami, pp 433-472

DeMartini EE, Roberts DA (1990) Effects of giant kelp (Macrocystis) on the density and abundance of fishes in a cobble-bottom kelp forest. Bull Mar Sci 46:287-300

Doherty PJ, Fowler AJ (1994) An empirical test of recruitment limitation in a coral reef fish. Science 263:935-939

Druehl LD, Kemp L (1982) Morphological and growth responses of geographically isolated Macrocystis integrifolia populations when grown in a common environment. Can J Bot 60:1409-1413

Ebeling AW, Hixon MA (1991) Tropical and temperate reef fishes comparison of community structures. In: Sale PF (ed) The ecology of fishes on coral reefs. Academic, San Diego, pp 475-563

Filbee-Dexter K, Scheibling RE (2014) Sea urchin barrens as alternative stable states of collapsed kelp ecosystems. Mar Ecol Prog Ser 495:1-25

Foster MS, Schiel DR (1992) Zonation, El Niño disturbance, and the dynamics of subtidal vegetation along a $30 \mathrm{~m}$ depth gradient in two giant kelp forests. In Proceedings of the International Temperate Reef Symposium vol. 2, pp. 151-162

Fuenzalida R (1992) Proceso de surgencia en la región norte de Chile, latitudes $20^{\circ} 30^{\prime} \mathrm{S}-21^{\circ} 45^{\prime} \mathrm{S}$. Invest Cient Tecnol Ser Cienc Mar 2:79_ 104

Gelcich S, Hughes TP, Olsson P, Folke C, Defeo O, Fernández M, Foale S, Gunderson LH, Rodríguez-Sickert C, Scheffer M, Steneck RS, Castilla JC (2010) Navigating transformations in governance of Chilean marine coastal resources. Proc Natl Acad Sci U S A 107: 16794-16799

Godoy N (2000) Macrocystis integrifolia (Laminariales, Phaeophyta) en el norte de Chile: Distribución espacio-temporal y fauna asociada. Marine Biologist Thesis. Facultad de Ciencias del Mar, Universidad Católica del Norte, Coquimbo, Chile. 80 pp.

Godoy N, Gelcich LS, Vásquez JA, Castilla JC (2010) Spearfishing to depletion: evidence from temperate reef fishes in Chile. Ecol Appl 20:1504-1511

Graham MH, Vásquez JA, Buschmann AH (2007) Global ecology of the giant kelp Macrocystis: from ecotypes to ecosystems. Oceanogr Mar Biol Annu Rev 45:39-88

Häussermann V, Försterra G (2001) A new species of sea anemone from Chile, Anemonia alicemartinae n. sp. (Cnidaria: Anthozoa). An invader or an indicator for environmental change in shallow water? Org Divers Evol 1:211-224

Hernández-Carmona GO, Garcia D, Robledo D, Foster M (2000) Restoration techniques for Macrocystis pyrifera (Phaeophyceae) populations at the southern limit of their distribution in Mexico. Bot Mar 43:273-284

Herrera L, Escribano R (2006) Factors structuring the phytoplankton community in the upwelling site off El Loa River in northern Chile. J Mar Syst 61:13-38 
Ho YB (1984) $\mathrm{Zn}$ and $\mathrm{Cu}$ concentration in Ascophyllum nodosum and Fucus vesiculosus (Phaeophyta, Fucales) after transplantation to an estuary contaminated with mine wastes. Conserv Recycl 7:329-337

Holbrook SJ, Carr MH, Schmitt RJ, Coyer JA (1990) Effect of giant kelp on local abundance of reef fishes: the importance of ontogenetic resource requirements. Bull Mar Sci 47:104-111

Jones GP (1984a) The influence of habitat and behavioural interactions on the local distribution of the wrasse Pseudolabrus celidotus. Environ Biol Fish 10:43-58

Jones GP (1984b) Populatlon ecology of the temperate reef fish Pseudolabrus celidotus Bloch \& Schnelder (Pisces Labridae). 1. Factors influencing recruitment. J Exp Mar Biol Ecol 75:257-276

Krumhansl KA, Bergman JN, Salomon AK (2017) Assessing the ecosystem-level consequences of a small-scale artisanal kelp fishery within the context of climate-change. Ecol Appl 27:799-813

Laudien J, Villegas MJ, Sielfeld W, Arntz WE (2018) Photographs of a foresting experiment in Chipana Bay. In: Laudien J et al (eds) Foresting experiment in Chipana Bay, Chile, Pangaea. Alfred Wegener Institute, Helmholtz Center for Polar and Marine Research, Bremerhaven. https://doi.org/10.1594/PANGAEA. 889035

Levin PS (1991) Effects of microhabitat on recruitment variation in a Gulf of Maine reef fish. Mar Ecol Prog Ser 75:183-189

Levin PS (1993) Habitat structure, conspecific presence and spatial variation in the recruitment of a temperate reef fish. Oecologia 94:176-185

Levin PS (1994) Small-scale recruitment variation in a temperate fish: the roles of macrophytes and food supply. Environ Biol Fish 40:271-281

Levin PS, Hay M (1996) Responses of temperate reef fishes to alterations in algal structure and species composition. Mar Ecol Prog Ser 134:37-47

Ling SD, Scheibling RE, Rassweiler A, Johnson CR, Shears N, Connell SD, Salomon AK, Norderhaug KM, Pérez-Matus A, Hernández JC, Clemente S, Blamey LK, Hereu B, Bellesteros E, Sala E, Garrabou J, Cebrian E, Zabala M, Fujita R, Johnson LE (2015) Global regime shift dynamics of catastrophic sea urchin overgrazing. Philos Trans R Soc B 370:20130269

Macaya EC, Boltaña S, Hinojosa IA, Macchiavello JE, Valdivia NA, Vásquez NR, Buschmann AH, Vásquez JA, Vega J, Thiel M (2005) Presence of sporophylls in floating kelp rafts of Macrocystis spp. (Phaeophyceae) along the Chilean Pacific coast. J Phycol 41:913-922

Macaya EC, Zuccarello CC (2010) Genetic structure of the giant kelp Macrocystis pyrifera along the Southeastern Pacific. Mar Ecol Prog Ser 420:103-112

Marsden DA, DeWreede RE, Levings CD (2003) Survivorship and growth of Fucus gerdneri after transplant to an acid mine drainage-polluted area. Mar Pollut Bull 46:65-73

McPeak R (1977) Kelp Habitat Improvement Project. Annual report 1974-1975. California Institute of Technology, Pasadera, pp 92-102

Medina M, Vega C, Araya M (2004) Alimentación y relaciones tróficas de peces costeros de la zona norte de Chile. Investig Mar 32:33-47

Miller RJ, Lafferty KD, Lamy T, Kui L, Rassweiler A, Reed DC (2018) Giant kelp, Macrocystis pyrifera, increases faunal diversity through physical engineering. Proc R Soc B 285:20172571

Muñoz AA, Ojeda FP (2000) Ontogenetic changes in the diet of the herbivorous Scartichthys viridis in a rocky intertidal zone in central Chile. J Fish Biol 56:986-998

Nuñez L, Vásquez JA (1987) Observaciones tróficas y de distribución espacial de peces asociados a un bosque submareal de Lessonia trabeculata. Estud Oceanol 6:79-85

O'Brien BS, Mello K, Litterer A, Dijkstra JA (2018) Seaweed structure shapes trophic interactions: a case study using a mid-trophic level fish species. J Exp Mar Biol Ecol 506:1-8
Palma W, Escribano R, Rosales SA (2006) Modeling study of seasonal and inter-annual variability of circulation in the coastal upwelling site of the El Loa River off northern Chile. Estuar Coast Shelf Sci 67:93-107

Parsons DF, Suthers IM, Cruz DO, Smith JA (2016) Effects of habitat on fish abundance and species composition on temperate rocky reefs. Mar Ecol Prog Ser 561:155-171

Pérez-Matus A, Ferry-Graham LA, Cea A, Vásquez JA (2007) Community structure of temperate reef fishes in kelp-dominated subtidal habitats of northern Chile. Mar Freshw Res 58:1069-1085

Pérez-Matus A, Pledger S, Díaz FJ, Ferry LA, Vásquez JA (2012) Plasticity in feeding selectivity and trophic structure of kelp forest associated fishes from northern Chile. Rev Chil Hist Nat 85:29-48

Pérez-Matus A, Sánchez F, González-But JC, Lamb RW (2016) Understory algae associations and predation risk influence broadscale kelp habitat use in a temperate reef fish. Mar Ecol Prog Ser 559:147-158

Pérez-Matus A, Carrasco SA, Gelcich S, Fernandez M, Wieters EA (2017) Exploring the effects of fishing pressure and upwelling intensity over subtidal kelp forest communities in central Chile. Ecosphere 8:e01808

Perreault M-C, Borgeaud IA, Gaymer CF (2014) Impact of grazing by the sea urchin Tetrapygus niger on the kelp Lessonia trabeculata in Northern Chile. J Exp Mar Biol Ecol 453:22-27

Pinto R (1989) Caracterización de la flora algológica del área de Iquique, Norte de Chile. Vultur 1:1-16

Rice DW, Dean TA, Jacobsen FR, Barnett AM (1989) Transplanting of giant kelp Macrocystis pyrifera in Los Angeles Harbor and productivity of kelp population. Bull Mar Sci 44:1070-1080

Romero H (2003) Algae: Macroalgas del norte de Chile. Programa Biodiversidad. Universidad Arturo Prat, Iquique $14 \mathrm{pp}$

Rovira J (2008) Estrategia Nacional de Biodiversidad y convenios internacionales. In: Rovira J, Ugalde J, Stutzin M (Eds.) Biodiversidad de Chile: Patrimonio y Desafios. Comisión Nacional del Medio Ambiente (CONAMA), pp 580-598

Ruz CS, Muth AF, Tala F, Pérez-Matus A (2018) The herbivorous fish, Aplodactylus punctatus, as a potential facilitator of dispersal of kelp, Lessonia trabeculata, in Chile. J Exp Mar Biol 500:112-119

Sale PF, Douglas WA (1981) Precision and accuracy of visual census technique for fish assemblages on coral patch reefs. Environ Biol Fish 6:333-339

Santander E, Rojas E, Moraga R, Salinas P (2017) Respuesta de la abundancia y estructura de tamaño del bacterioplancton a diferentes condiciones oceanográficas en bahía Chipana ( $\left.21^{\circ} 20^{\prime} \mathrm{S}\right)$. Rev Biol Mar Oceanogr 52:451-465

Santelices B, Ojeda FP (1984) Effects of canopy removal on the understory algal community structure of coastal forests of Macrocystis pyrifera from southern South America. Mar Ecol Prog Ser 14: 165-173

Schmitt RS, Holbrook SJ (1990) Contrasting effects of giant kelp on dynamics of surfperch populations. Oecologia 84:419-429

SERNAPESCA (1998-2009). Anuarios Estadísticos de Pesca del Servicio Nacional de Pesca. Publicaciones del Departamento de Sistemas de Información y Estadísticas Pesqueras, SERNAPESCA, Valparaiso. Available at http://www.sernapesca. cl/index.php

Sielfeld W, Laudien J, Vargas M, Villegas M (2010) El Niño induced changes of the coastal fish fauna off northern Chile and implications for ichthyogeography. Rev Biol Mar Oceanogr 45:705-722

Sjøtun K, Fredriksen S (1995) Growth allocation in Laminaria hyperborea (Laminariales, Phaeophyceae) in relation to age and wave exposure. Mar Ecol Prog Ser 126:213-222

Stachowicz JJ (2001) Mutualism, facilitation, and the structure of ecological communities. Bioscience 51:235-246

Steneck R, Graham MH, Bourque BJ, Corbett D, Erlandson JM, Estes JA, Tegner MJ (2002) Kelp forest system: biodiversity, stability, 
resilience and future. Foundation of Environmental Conservation. Environ Conserv 29:436-459

Stotz W, González SA, Caillaux L, Aburto J (2003) Quantitative evaluation of the diet and feeding behaviour of the carnivorous gastropod, Concholepas concholepas (Bruguière, 1789) (Muricidae) in subtidal habitats in the Southeastern Pacific upwelling system. J Shellfish Res 22:147-164

Stotz WB, Aburto J, Caillaux LM, González SA (2016) Vertical distribution of rocky subtidal assemblages along the exposed coast of northcentral Chile. J Sea Res 107:34-47

Teagle H, Hawkins SJ, Moore PJ, Smale DA (2017) The role of kelp species as biogenic habitat formers in coastal marine ecosystems. J Exp Mar Biol Ecol 492:81-98

Tegner MJ, Dayton PK (1987) El Niño effects on Southern California kelp forest communities. Adv Ecol Res 17:243-279

Terazono Y, Nakamura Y, Imoto Z, Hiraoka M (2012) Fish response to expanding tropical Sargassum beds on the temperate coasts of Japan. Mar Ecol Prog Ser 464:209-220

Trebilco R, Dulvy NK, Stewart H, Salomon AK (2015) The role of habitat complexity in shaping the size structure of a temperate reef fish community. Mar Ecol Prog Ser 532:197-211

Vanella F, Fernández D, Romero M, Calvo J (2007) Changes in the fish fauna associated with a sub-Antarctic Macrocystis pyrifera kelp forest in response to canopy removal. Polar Biol 30:449-457

Varas E, Ojeda FP (1990) Intertidal fish assemblages of the central Chilean coast: diversity, abundance and trophic patterns. Rev Biol Mar Valparaíso 25:59-70

Vargas M, Sielfeld W (1997) Playa Chipana (2119'S, $\left.70^{\circ} 04^{\prime} \mathrm{W}\right)$ : a nursery and smolting area for marine coastal fish in northern Chile. Arch Fish Mar Res 45:167-182

Vásquez JA (1992) Lessonia trabeculata, a subtidal bottom kelp in northern Chile: a case study for a structural and geographical comparison. In: Seeliger U (ed) Coastal plant communities of Latin America. Academic, San Diego, pp 77-89

Vásquez JA (1993) Abundance, distributional patterns and diets of main herbivorous and carnivorous species associated to Lessonia trabeculata kelp beds in northern Chile. Serie Ocasional Universidad Catolica del Norte 2:213-229

Vásquez JA, Santelices B (1984) Comunidades de macroinvertebrados en discos de Lessonia nigrescens Bory (Phaeophyta) en Chile central. Rev Chil Hist Nat 57:131-154

Vásquez JA, Castilla JC, Santelices B (1984) Distributional patterns and diets of four species of sea urchins in giant kelp forest (Macrocystis pyrifera) of Puerto Toro, Navarino Island, Chile. Mar Ecol Prog Ser 19:55-63

Vásquez JA, Véliz DA, Pardo LM (2001) Biodiversidad de macroinvertebrados bajo las grandes algas. In: Alveal K, Antezana T (eds) Sustentabilidad de la Biodiversidad. Un problema actual, bases científico-técnicas, teorizaciones y perspectivas. Ediciones Universidad de Concepción, Chile, pp 293-308

Vásquez JA, Vega JMA (2004) El Niño 1997-98 en el norte de Chile: efectos en la estructura y en la organización de comunidades submareales dominadas por algas pardas. In: Avaria S, Carrasco J, Rutllant J, Yáñez E (eds) El Niño-La Niña 1997-2000. Sus Efectos en Chile. CONA, Valparaíso

Vásquez JA, Vega JMA, Buschmann AH (2006) Long term variability in the structure of kelp communities in northern Chile and the 1997-98 ENSO. J Appl Phycol 18:505-519

Vásquez JA, Piaget N, Vega JMA (2012) The Lessonia nigrescens fishery in northern Chile: "how you harvest is more important than how much you harvest". J Appl Phycol 24:417-426

Vega JMA, Vásquez JA, Buschmann AH (2005) Population biology of the subtidal kelps Macrocystis integrifolia and Lessonia trabeculata (Laminariales; Phaeophyceae) in an upwelling ecosystem of northern Chile: interannual variability and El Niño 1997-98. Rev Chil Hist Nat 78:33-50

Vega JMA, Broitman BR, Vásquez JA (2014) Monitoring the sustainability of Lessonia nigrescens (Laminariales, Phaeophyceae) in northern Chile under strong harvest pressure. J Appl Phycol 26:791-801

Vergés A, Doropoulos C, Malcolm HA, Skye M, Garcia-Pizá M, Marzinelli EM, Campbell AH, Ballesteros E, Hoey AS, VilaConcejo A, Bozec Y-M, Steinberg PD (2016) Long-term empirical evidence of ocean warming leading to tropicalization of fish communities, increased herbivory, and loss of kelp. Proc Natl Acad Sci U S A 113:13791-13796

Villegas M, Laudien J, Sielfeld W, Arntz W (2008) Macrocystis integrifolia and Lessonia trabeculata (Laminariales; Phaeophyta) kelp habitat structures and associated macrobenthic comunity off northern Chile. Helgol Mar Res 62:33-44

Villegas M, Laudien J, Sielfeld W, Arntz WE (2018a) Fish abundances in a foresting experiment in Chipana Bay. In: Laudien $\mathrm{J}$ et al (eds) Foresting experiment in Chipana Bay, Chile, Pangaea. Alfred Wegener Institute, Helmholtz Center for Polar and Marine Research, Bremerhaven. https://doi.org/10.1594/PANGAEA. 888802

Villegas M, Laudien J, Sielfeld W, Arntz WE (2018b) Algae cover in a foresting experiment in Chipana Bay. In: Laudien $\mathrm{J}$ et al (eds) Foresting experiment in Chipana Bay, Chile, Pangaea. Alfred Wegener Institute, Helmholtz Center for Polar and Marine Research, Bremerhaven. https://doi.org/10.1594/PANGAEA. 888803

Villegas M, Laudien J, Sielfeld W, Arntz WE (2018c) Invertebrata abundances in a foresting experiment in Chipana Bay. In: Laudien $J$ et al (eds) Foresting experiment in Chipana Bay, Chile, Pangaea. Alfred Wegener Institute, Helmholtz Center for Polar and Marine Research, Bremerhaven. https://doi.org/10.1594/PANGAEA.888804

Villegas M, Laudien J, Sielfeld W, Arntz WE (2018d) Fish abundances in a Macrocystis integrifolia kelp bed at Chipana Bay, Chile. In: Villegas $M$ et al (eds) Coastal fish abundance at Chipana Bay, Chile, Pangaea. Alfred Wegener Institute, Helmholtz Center for Polar and Marine Research, Bremerhaven. https://doi.org/10.1594/PANGAEA.890747

Villegas M, Laudien J, Sielfeld W, Arntz WE (2018e) Fish abundances in a Lessonia trabeculata kelp bed at Chipana Bay, Chile. In: Villegas $\mathrm{M}$ et al (eds) Coastal fish abundance at Chipana Bay, Chile. Pangaea. Alfred Wegener Institute, Helmholtz Center for Polar and Marine Research, Bremerhaven. https://doi.org/10.1594/ PANGAEA.890748

Villegas M, Laudien J, Sielfeld W, Arntz WE (2018f) Fish abundances in Lessonia trabeculata patches on barren ground at Chipana Bay, Chile. In: Villegas $\mathrm{M}$ et al (eds) Coastal fish abundance at Chipana Bay, Chile, Pangaea. Alfred Wegener Institute, Helmholtz Center for Polar and Marine Research, Bremerhaven. https://doi.org/10.1594/ PANGAEA.890749

Westermeier R, Murúa P, Patiño D, Muñoz L, Müller DG (2014a) Giant kelp (Macrocystis) fishery in Atacama (northern Chile): biological basis for management of the integrifolia morph. J Appl Phycol 26: 1071-1079

Westermeier R, Murúa P, Patiño D, Muñoz L, Atero C, Müller DG (2014b) Repopulation techniques for Macrocystis integrifolia (Phaeophyceae: Laminariales) in Atacama, Chile. J Appl Phycol 26:511-518

Westermeier R, Murúa P, Patiño DJ, Muñoz L, Müller DG (2016) Holdfast fragmentation of Macrocystis pyrifera (integrifolia morph) and Lessonia berteroana in Atacama (Chile): a novel approach for kelp bed restoration. J Appl Phycol 28:2969-2977

Witman JD, Lamb RW (2018) Persistent differences between coastal and offshore kelp forest communities in a warming Gulf of Maine. PLoS One 13:e189388 